Maria Lindholm

Department of Industrial Engineering and Management, University of Oulu,

P.O. Box 4610, 90014, Finland

E-mail: maria.lindholm@oulu.fi

Arto Reiman

Department of Industrial Engineering and Management, University of Oulu,

P.O. Box 4610, 90014, Finland

E-mail: arto.reiman@oulu.fi

Henri Jounila

Department of Industrial Engineering and Management, University of Oulu,

P.O. Box 4610, 90014, Finland

E-mail: henri.jounila@oulu.fi

Seppo Väyrynen

Department of Industrial Engineering and Management,

University of Oulu,

P.O. Box 4610, 90014, Finland

E-mail: seppo.vayrynen@oulu.fi

Otso Ervasti

Senior Medical Officer

VR-Group ltd, Finnish Railways

PO BOX 488

FI-00101 Helsinki

E-mail: otso.ervasti@vr.fi

Anna Melleri

Risk manager and Head of Occupational Safety

VR-Group Ltd, Finnish Railways

PO BOX 488

FI-00101 Helsinki

E-mail: anna.melleri@vr.fi 
Maria Lindholm is a researcher at the University of Oulu, Finland, at the Department of Industrial Engineering and Management at the Well-Being at Work and Productivity research team. Her main research interests are occupational safety and well-being at work. She completed her MSc in Industrial Engineering and Management in 2016. The main purpose of her thesis was to develop new safety meetings and ways to keep them.

Arto Reiman works currently as a research team leader at the University of Oulu, Finland. His doctoral thesis focused on work system design and management at the delivery transportation branch. His research team focuses on the theme of well-being at work and productivity under industrial engineering and management discipline. In addition to academic career he has worked as an OHS manager and a HSEQ consultant. His research interests include OHS, ergonomics and human factors and how they can be included in design and development processes in order to improve well-being at work and productivity.

Henri Jounila received his MSc in Process Engineering degree programme, University of Oulu, Finland, 2002. Now he is continuing with doctoral studies at the University of Oulu. After his graduation, Jounila started to work as a researcher and a teacher at the University of Oulu. He has worked with various research and development groups at the University of Oulu and for different companies and organizations. The main research interests have been occupational health and safety, attitudes towards safety and safety management.

Seppo Väyrynen is Professor of Work Science at the University of Oulu, Finland. Before that, he mainly worked for the Finnish Institute of Occupational Health. He has passed MSc and DSc examinations in the context of mechanical engineering. The theses were dealing with working environment and ergonomics development, linked to engineering design and industrial maintenance management. In addition to heading many research projects in the Research Unit of Industrial Engineering and Management, he is supervising doctoral students and MSc thesis workers. His main research interests include ergonomics and human factors; user-centred design; usability; participative approaches to development, design, innovations and management; organisational development; safety-conscious design; safety management and culture; integrated management systems (HSEQ); well-being and productivity at work. He has published around 395 scientific and professional articles or book chapters.

Otso Ervasti is working at Finnish Railways as chief/senior medical officer. He is the doctor of medicine and specialist in the occupational health, traffic medicine and insurance medicine. He is the vice president of the Board of The Roos Foundation.

Anna Melleri is working at Finnish Railways Safety and Security department as risk manager and head of occupational safety. She is MSc specialized in environment and safety engineering at Tampere university of Technology (2001). She has worked in different organizations in the field of $\mathrm{OSH}$, insurance and risk management. She is member of the Board of The Roos Foundation. 


\title{
Personnel's perceptions of occupational safety in rail transport work
}

\begin{abstract}
In rail transport work, a wide variety of occupational accidents occur. This questionnaire study aims to investigate the occupational safety (OS) challenges and needs recognised by railway personnel $(N=9,404)$. Altogether, 1,087 people answered. Answers were categorised thematically, and differences in perceptions between personnel groups and between different business sectors inside the company were identified. Differences between the category distributions were analysed with chisquare tests. Participatory approaches to improve OS emerged from the answers, e.g. attitudes, discussing and training OS. Statistically significant differences e.g. in the above-mentioned themes were found between the groups. The results provide vital information for the company to direct OS actions to the right business sectors. This study shows how personnel can contribute important views and feedback to OS development processes in a new way. The results suggest that more focused OS actions are needed. Guidance for the allocation, prioritisation and scheduling are provided.
\end{abstract}

Keywords: rail transport work; railway personnel; perception; occupational safety; employees; management; business sector; participation; participatory approach; idea generation; safety meeting

\section{Introduction}

Rail transport work consists of various tasks, including, for instance, catering, driving, maintenance, shunting, loading and ticketing (European Agency for Safety and Health at Work, 2011). The tasks are performed in a variety of environments such as inside the trains, in control rooms, in terminals, in maintenance halls and outdoors in all weather conditions, with different actors involved, such as drivers, station and on-train staff, passengers and the public in general (Wilson, 2014).

Due to this safety-critical complexity, a wide variety of accidents can and do occur (Chau et al., 2007). Wilson (2013) emphasised the distributed intricacies of railways and highlighted the need to understand various technical, organisational, economic and human components of the work, as well as their interactions, in order to succeed in developing railway work. Furthermore, Wilson et al. (2008) noted that the design, planning and management of such complex systems involve challenges related to incorporating both safety and productivity.

In addition to the risk of accidents, employees in the rail transport sector are exposed to different load stressors that might affect their ability to work. A study by the European Agency for Safety and Health at Work (2011) emphasised stressor factors such as organisational changes and outsourcing, solitary work, working time issues, long-distance transport, deficiencies in ergonomics and workplace design, and climatic conditions.

Formal and enacted organisational policies, procedures and practices affect employees' perceptions of occupational safety (OS). When employees perceive that they have organisational support, they tend to express more job satisfaction and are more compliant with OS rules, which then affects accident rates (Gyekye and Salminen, 2007). Management's commitment, the organisational value setting, personnel's involvement, stable employment processes, and proper OS training and guidance 
processes have all been identified as essential factors that contribute to the safety climate (Brown and Holmes, 1986; Dedobbeleer and Beland, 1991; DeJoy, 1994; Murphy et al., 2014; Schneider and Gunnarson, 1991; Zohar, 1980).

Organisational OS communication practices also affect the safety climate. Such communication may include 'top-down' and 'bottom-up' perspectives, depending, for example, on the possibilities for participatory processes and communication arenas (Glendon and Stanton, 2000). One way to communicate OS issues to employees is in an OS meeting (also known as a safety talk, a toolbox meeting or a crew safety meeting), which is a concept involving regular meetings where OS-related matters are discussed and shared by the relevant stakeholders (Reese, 2001; Reese, 2015; Simola, 2005).

Houghton et al. (2016) and Schock et al. (2010) encouraged to continue the utilisation of participatory approaches that concentrate on human factors and ergonomics in complex railway settings. This study aims to continue that discussion by providing an in-depth analysis of personnel's views on OS development needs in a large-scale railway business. The study aims to answer the following research questions (RQs):

RQ1: What kinds of OS challenges and needs are identified by railway personnel?

RQ2: What kind of differences on OS challenges and needs can be identified between personnel groups and between the different business sectors?

In order to illustrate the practical utilisation of the RQ1 and RQ2 results, the procedure and results of a participatory process of forming safety meetings are described. This is called a participatory design case.

\section{$2 \quad$ Methods and material}

\subsection{Study design}

Qualitative answers from a case-specific safety climate questionnaire are utilised in this study to find out the different types of OS challenges that personnel face during their work. RQ1 is answered based on a qualitative analysis of the open-ended answers in the questionnaire, and RQ2 is answered based on a quantitative analysis of the identified themes. As the case company also wanted to use the answers in practice, the material was further processed in the participatory design science-oriented case.

\subsection{Case company}

The case company is a government-owned Finnish railway group that had around 9,400 employees in 2014. The company is the main operator in the railway field in Finland and is divided into five large business sectors: passenger services (2,750 employees), logistics $(1,650)$, infrastructure engineering $(1,900)$, maintenance $(1,250)$ and train operations $(1,400)$. In 2014, the average age of the entire group was 44.9 years, and the average length of service was 18 years. The group's accident frequency rate (accidents that required one sick day or more per one million working hours) was 18.9 in 2014 and 15.3 in 2015. (VR Group, 2015)

\subsection{Data collection methods}

Data collection was carried out via a safety climate questionnaire and complementary focus group interviews. The questionnaire, including 71 quantitative questions and one qualitative question, was tailored based on the research team's experience, the company's past personnel questionnaires and the research literature to address the 
company's need to obtain new knowledge about the personnel's OS attitudes. The research team and the case company's representatives participated in the questionnaire design process. The questionnaire was tested $(N=34)$ and complemented with five interviews before it was finalised. The questionnaire was sent to the personnel $(N=$ $9,404)$ via email or mail in early 2014. Reminders about the questionnaire were sent to those who received the questionnaire via email. In total, 3,042 employees responded to the questionnaire, for a response rate of 32.3\%. (Väyrynen et al., 2015) In this study, the focus is on qualitative data, i.e. on the analyses and further usage of the answers to the following open-ended question: 'Tell us your own ideas on how to improve OS in your company (e.g. related to instructions, training, communication or work methods)'. The focus group interviews were used in the case study to answer the practical needs raised by the company.

\subsection{Material}

Of the 3,042 respondents, 1,087 answered the open-ended question, giving general comments about the state of OS in the case company or specific ideas on how to improve it. Each of the respondents provided one or more comments and/or ideas.

The respondents were mainly male, $876(80.6 \%)$, which is similar to the gender distribution of the company personnel (82\%), and $175(16.1 \%)$ were women, while 36 (3.3\%) of the respondents did not supply information about their gender. Of the respondents, $281(25.9 \%)$ were young (under 34 years old), 499 (45.9\%) were considered middle-aged (from 34 to 54 years) and 298 (27.4\%) were over 54 years old. Nine respondents did not supply information about their age. Meanwhile, 659 (60.6\%) of the respondents were employees, and 415 (38.2\%) acted as experts or worked at the management level; 13 respondents did not offer information about their work status. The respondents were considered highly experienced, as $842(77.5 \%)$ of them had more than 10 years of work experience.

The different business sectors were represented broadly by the respondents. Of the respondents, $275(25.2 \%)$ were from passenger services, $137(12.6 \%)$ were from logistics, $220(20.2 \%)$ were from infrastructure engineering, $148(13.6 \%)$ were from maintenance and $247(22.7 \%)$ were from train operations. In addition, 68 (5.5\%) belonged to other sectors or did not supply information about their business sector. The respondents' gender, age and work status distributions in the main business sectors are presented in Table 1.

\section{Table 1.}

\subsection{Data analysis}

\subsubsection{Questionnaire results}

This study is based on open-ended answers and their thematic categorisation. Thus, it is qualitative and interpretative in nature. However, the thematic categorisation provided a possibility for quantitative analyses.

Thematic categorisation was conducted by applying the open-coding analysis approach (Järvinen, 2004). During the analysis, one researcher (ML) first read all the answers to the open-ended question and sketched identified 37 themes for categorisation purposes. In the second round of analysis, the research team categorised the open answers according to the 37 themes. Each answer may have fit into one or more of the themes.

In order to find out whether there were any significant differences in the themes between the personnel groups and between the business sectors, quantitative analyses 
were conducted. IBM SPSS version 24 was used to conduct Chi-square tests. The answers that did not contain status information were ignored. The level of statistical significance was defined as $p<.05$.

\subsubsection{Participatory design case}

The participatory design case provided in this study was based on heuristic design science premises (Van Aken, 2004), as the data were processed iteratively in three phases until the saturation of company-level acceptance was reached. The companyoriginated aim for the participatory design case was to renew the company's safety meeting contents to address the needs identified by the personnel (Jounila et al., 2015; Reiman et al., 2016). As some of the themes were viewed as topics not to be discussed in the safety meetings (e.g. purely technical development needs), they were not deemed suitable as safety meeting topics. By applying axial coding premises, the research team selected 26 proposals for safety meeting topics from the 37 themes (Phase 1).

The 26 proposed topics were discussed in-depth in Focus Group I (Phase 2), and 20 safety meeting themes were selected by consensus as the topics most fitting to the practical needs of the company. In finalising Phase 2, the research team applied the appropriate research literature and company-specific OS policies and practices to the content of the safety meeting topics. The final safety meeting topics and their contents were discussed in-depth in Focus Group II and finalised in Phase 3. A researcher (ML), the case company's senior medical officer, head of OS, and a local traffic's industrial safety delegate participated in the focus group meetings.

\section{$3 \quad$ Results}

\subsection{Identified themes (RQ1)}

Each open-ended answer was analysed separately, and a certain theme or themes were identified to fit the answer. For example, the answer 'Increasing OS training and making communication and working methods more effective will improve OS fundamentally' clearly fits all of the following themes: 'amount and quality of training', 'communication practices' and 'intensification of working methods'.

The answers show that the personnel wanted to discuss OS and hoped to have more high-quality training. Overall, many respondents emphasised beliefs and expectations regarding employees' skills and attitudes, as seen in the following answers: 'Think before acting' and 'Common attitudes need to be shaped; too many of the experienced employees say that "nothing will happen to me" and risks are taken'. In addition, management's skills, attitudes and ability to act as an example were highlighted in various answers, such as 'Management's example and lowering the threshold of interference when needed are crucial in improving the OS level' and 'Improve the attitudes and know-how of supervisors to the right level'.

Answers included comments related to feeling hurried and rushed, such as 'Increasing the hurry always increases the risk of accidents' and 'Anticipation in planning the work and making timetables more flexible = no hurrying'. The themes 'Communication practices' and 'Ability to listen to employees' concern communication between managers and employees as well as generally informing employees and considering their opinions. The personnel hoped that communication and the flow of information could be simpler, faster and clearer. Given its straightforwardness, the next comment reflects the theme 'Communication practices' well: 'Some of the announcements and instructions disappear in the huge amount of information and don't get the attention of employees'. The theme 'Visible changes' also indicates that 
respondents hoped to witness actual changes in the workplace and not just hear of the intention to do something.

The theme 'Interfering in dangerous situations' indicates that many of the respondents hoped that different working situations and hazards would be identified and dealt with faster, as expressed in the next answer: 'When OS observations of defects or risks have been made, the problems should be dealt with immediately'. Many of the respondents also wanted more systematic responses to risky situations.

The themes 'Working tools', 'Protective equipment', 'Radiotelephone' and 'IT systems' represent comments about working tools, the use and usability of personal protective equipment, communication tools and IT systems. The following answers clearly reflect the majority of these themes: 'Get communication tools in good condition', 'Improve the OS report systems' user friendliness' and 'Get equipment and staff into shape'. The condition of working tools and working conditions also emerged from the answers and were interconnected. For example, in the respondents' opinion, train maintenance was insufficient, and this reflected on the working conditions. Overall, the answers revealed that working conditions were considered important, and the respondents hoped that rapid action could be taken to keep working conditions safe and acceptable.

As a summary of the qualitative analysis and RQ1 answers, Figure 1 depicts the 37 identified themes and their relative size.

\section{Figure 1.}

\subsection{Differences between personnel groups (RQ2)}

The answer distribution of the 37 themes between employees and others (management and experts) is shown in Table 2. Chi-square tests revealed significant differences in certain themes. The themes 'Discussing OS and OS observation-processing practices', 'Employees' attitudes', 'Rewarding practices', 'Training for supervisors' and 'IT systems' were more common among the others than among the employees. 'Working time and breaks', 'Working tools', 'Constant hurry', 'Work environment' and 'More personnel to work' were themes emphasised among the employees.

\section{Table 2.}

\subsection{Differences between business sectors (RQ2)}

The answer distribution of the 37 themes across the business sectors is shown in Table 3. Statistically significant differences were found in certain themes. The theme 'Management's attitudes' was more common in the train operations and infrastructure engineering sectors. The themes 'Working time and breaks', 'Constant hurry' and 'Actions of managers' were largely emphasised in the train operations sector, while the theme 'Work environment' was more common in the passenger services and logistics sectors. Finally, the theme 'OS observation-making processes' was emphasised more in the passenger services sector.

\section{Table 3.}

\subsection{Participatory design case}

The results of Phase 1 and Phase 2 are presented in Table 4. Four proposed themes were omitted from the final safety meeting themes (see Table 4), while some proposed 
themes were merged. The safety meeting material was finalised in Phase 3 and included content and instructions for the 20 new safety meeting themes.

\section{Table 4.}

\section{Discussion}

Employee involvement in OS development processes increases the potential for success in safety promotion. Traditional organisational motivation theories such as Maslow's (1943), as well as topical OS promotion approaches (see e.g. European Agency for Safety and Health at Work, 2012), acknowledge different ways to improve the sense of community within an organisation. A sense of community, broad participation in development actions and an ability to contribute to decision making improve the possibilities to adapt more easily to different kinds of changes (Framke and Sørensen, 2015). Personnel participation can be fulfilled in various ways and at different levels. In this case, participation was implemented broadly through a large-scale safety climate questionnaire that was processed in participatory design case sessions that led to concrete outcomes, i.e. renewed safety meetings incorporated into the company's OS practices.

A wide variety of OS development needs were identified from the answers. Thus, the findings of this study are consistent with earlier studies on OS at railways (see e.g. Chau et al., 2007; Wilson, 2013; Wilson et al., 2008). In a sense, the different development needs highlight the known complex nature of railway work. The researchers analysed 37 themes, and none of these themes emerged as dominant, since the relative shares of each theme were rather small. Even the most common theme, 'Discussing OS and OS observation-processing practices', was identified in only 152 out of the total 1,087 answers.

However, as a point to be emphasised in future OS management processes, a participatory yet human-centric approach seemed to emerge from the answers. A need to develop practices related to 'Discussing OS and OS observation-processing practices' between different parties was the most common theme, followed by a need to improve OS training. In addition, different stakeholders' attitudes (both employees' and management's), as the next most common themes, emphasise the need for more indepth safety climate improvements. The psychosocial risk factors of working time problems and the feeling of constantly being in a hurry were also emphasised.

There were statistically significant differences between the groups. For instance, the themes 'Working time and breaks', 'Constant hurry' and 'Work environment' showed significant differences between the employees and others (management and experts) and between the business sectors. Furthermore, analyses show that the management and experts noticed the need to improve OS discussion processes inside the company ('Discussing OS and OS observation-processing practices'). They also recognised the importance of attitudes towards safety, as the theme 'Employees' attitudes' was the second most common theme in this group. The employees' focus was more evenly distributed across the themes and more practical themes such as working time problems ('Working time and breaks' and 'Constant hurry'), and themes 'Working tools' and 'Work environment' were identified in their answers.

The theme 'Management's attitudes' was emphasised in the train operations and infrastructure engineering sectors. On the other hand, the themes 'Working time and breaks', 'Constant hurry' and 'Actions of managers' were more common in the train operations sector, and the theme 'Work environment' was emphasised more often in the 
logistics sector. These themes possibly reflect the work tasks in the different business sectors.

The results, and especially the statistically significant differences between personnel groups and between the different business sectors, provide unique practical implications for the company. Knowledge of the significant differences can enable the company to allocate different OS development actions and implementations to specific groups and business sectors, and as well schedule them. The personnel should also be informed of the results and focused actions. If the company conducts the survey every few years to investigate the personnel's perceptions of OS challenges and needs, they can keep focusing their OS actions on specific groups and business sectors. This also enables and ensures the personnel's participation first in a wide range and then in small groups when concrete actions are planned.

\subsection{Safety meetings}

In order to highlight the possibilities for processing the employees' ideas and opinions, a participatory design case for developing the themes and content of safety meetings was introduced. The case company's supervisor-led safety meetings are used regularly (bi-weekly or monthly) to share and discuss OS issues. The participatory design case described in this study provides an iterative theme-specification process complemented by a process for creating actual training material from the themes. The iterative and participatory approach to creating OS material described in this study supports the findings of, for instance, Simola (2005).

However, the material is insufficient to analyse and discuss the practical utilisation of the new safety meeting material. According to the case company's head of OS, new safety meeting material is in use and was shared through the intranet, with minor adjustments, in 2016. Thus, a follow-up study to define the utilisation and possible problems of the new safety meeting material should be performed.

In addition, for future development purposes, more participative methods such as participative narrative methods for supporting participation and communication (Rajala and Väyrynen, 2013) and multimedia could be adopted for use in safety meetings to help demonstrate and intensify the OS training. Hsia (1968) showed almost 50 years ago that using visual and voice information together increases the reception of the message. Video material and its analysis provide possible means to visualise potential problems and faults at work. For example, Reiman and Putkonen (2012) studied ways in which different stakeholders in logistics value chains can efficiently develop and produce concrete OS ideas by analysing video material. Such analyses could also be used in the safety meetings to help employees visualise and understand the risks associated with ergonomic discomfort and accidents and to identify possible solutions. These are areas where further study is needed. More empirical studies are required to determine whether such participatory safety meetings are more effective than traditional safety meetings. Furthermore, future studies should attempt to discover how participatory approaches affect employees' work satisfaction and safety knowledge compared with the traditional safety meetings structured as supervisors delivering lectures to their employees.

\subsection{Limitations}

Due to the large number of personnel, a safety climate questionnaire was chosen as the main data collection method. However, as emphasised by Sinclair (1991), there are certain problems related to questionnaires. An open-ended question provides an opportunity for various kinds of answers, and the interpretation of the answers can be 
challenging. In this study, the respondents were asked to share their ideas on 'how to improve OS in your company'. However, in addition to definite ideas, the answers included more general comments regarding the case company's OS practices and the condition of OS. If the respondents were asked directly to share ideas on how to develop safety meetings and their themes, the results of the participatory design case might have been different.

The benefits of using a questionnaire stem from its effectiveness and the manageability of the answers when the respondents' group is large, as the questions are the same for everybody. On the other hand, how seriously the respondents took the questions or whether the respondents misunderstood something cannot be determined; slight variations in the words used in a questionnaire or the context of a question can affect the results (Järvinen, 2004; Strauss and Corbin, 1998). The same principles apply to the researchers' analysis of the answers, as they can misunderstand the answers, and variations in the words used in the answers can affect the analysis.

\section{Conclusions}

Railway work consists of various tasks performed by actors. A wide variety of risks, including accidents and physical and psychosocial stress, exist. Railway work as a complex system challenges OS management practices. This study shows how personnel provided important views and feedback regarding OS development challenges and needs via a questionnaire. Further, this study described an iterative process of analysing and categorising the results. A broad range of OS development themes were identified from the answers. The results show that there are statistically significant differences inside the company in terms of perceptions of OS, both at the personnel level and at the business-sector level. Thus, more focused OS actions are needed. Knowledge of the significant differences can enable the company to choose correct OS development actions and implementations and allocate them to specific groups and business sectors, as well as to plan their schedules. Hence, it is recommended that large companies conduct a similar survey to obtain feedback on OS development challenges and needs from their personnel every few years and carry out focused improvements between the surveys. In addition, this study presented a participatory design case that showed how questionnaire material was processed for practical use by identifying the most important OS-related themes from the answers and providing a participatory design process to group themes into safety meeting topics and their related content.

\section{References}

Brown, R.L. and Holmes, H. (1986) 'The use of a factor-analytic procedure for assessing the validity of an employee safety climate model', Accident Analysis and Prevention, Vol. 18, pp.455-470.

Chau, N., Gauchard, G.C., Dehaene, D., Benamghar, L., Touron, C., Perrin, P.P. and Mur, J.M. (2007) 'Contributions of occupational hazards and human factors in occupational injuries and their associations with job, age and type of injuries in railway workers', International Archives of Occupational and Environmental Health, Vol. 80, No. 6, pp.517-525.

Dedobbeleer, N. and Beland, F. (1991) 'A safety climate measure for construction sites', Journal of Safety Research, Vol. 22, pp.97-103.

DeJoy, D.M. (1994) 'Managing safety in the workplace: an attribution theory analysis and model', Journal of Safety Research, Vol. 25, pp.3-17. 
European Agency for Safety and Health at Work (2011) OSH in Figures: Occupational Safety and Health in the Transport Sector - An Overview, Luxembourg.

European Agency for Safety and Health at Work (2012) Worker Participation Practices: A Review of EU-OSHA Case Studies. Literature Review, Luxembourg.

Framke, E. and Sørensen, O.H. (2015) 'Implementation of a participatory organisational-level occupational health intervention - focusing on the primary task', International Journal of Human Factors and Ergonomics, Vol. 3, No. 3-4, pp.254-270.

Glendon, A.I. and Stanton, N.A. (2000) 'Perspectives on safety culture', Safety Science, Vol. 34, No. 1, pp.193-214.

Gyekye, S. and Salminen, S. (2007) 'Workplace safety perceptions and perceived organizational support: Do supportive perceptions influence safety perceptions?', International Journal of Occupational Safety and Ergonomics, Vol. 13, No. 2, pp.189-200.

Houghton, R.J., White, C., Golightly, D. and Wilson, J.R. (2016) 'Span of control in supervision of rail track work', Cognition, Technology \& Work, Vol. 18, No. 2, pp.361-378.

Hsia, H. (1968) 'Output, error, equivocation, and recalled information in auditory, visual and audiovisual information processing with constraint and noise', Journal of Communication, Vol. 18, pp.325-353.

Jounila, H., Väyrynen, S. and Latva-Ranta, J. (2015) 'Aspects on safety indicators, management and culture in three big companies in Finland', in WOS 8th International Conference Proceedings: Smart Prevention for Sustainable Safety, WOS2015 Scientific Committee, pp.352-362.

Järvinen, P. (2004) On Research Methods, Opinpajan kirja, Tampere, Finland.

Maslow, A. (1943) 'A theory of human motivation', Psychological Review, Vol. 50, No. 4, pp.370-396.

Murphy, L.A., Robertson, M.M. and Carayon, P. (2014) 'The next generation of macroergonomics: integrating safety climate', Accident Analysis and Prevention, Vol. 68, No. 7, pp.16-24.

Rajala, H.K. and Väyrynen, S. (2013) 'Participative approach to strategy communication: a case of small- and medium-sized metal enterprises with a review after seven years', Human Factors and Ergonomics in Manufacturing \& Service Industries, Vol. 23, No. 4, pp.346-356.

Reese, C. (2001) Accident/Incident Prevention Techniques, $1^{\text {st }}$ ed., Taylor \& Francis, London.

Reese, C. (2015) Occupational Health and Safety Management: A Practical Approach, $3^{\text {rd }}$ ed., CRC Press, Boca Raton, FL.

Reiman, A., Jounila, H., Lindholm, M., Kisko, K. and Väyrynen, S. (2016) 'Occupational safety at rail transport - personnel's view for improvements', in Proceedings of the 48th Annual Conference of the Nordic Ergonomics and Human Factors Society, Kuopio, Finland, pp.262-266.

Reiman, A. and Putkonen, A. (2012) 'Ergonomics development needs in truck body design - from video analyses to solution proposals', International Journal of Human Factors and Ergonomics, Vol. 1, No. 1, pp.58-73.

Schneider, B. and Gunnarson, S. (1991) 'Organizational climate and culture: the psychology of the workplace', in Steffy, J. and Bray, D. (Eds.), Applying Psychology in Business, Lexington Books, MA, pp.542-551.

Schock, A., Ryan, B., Wilson, J., Clarke, T. and Sharples, S. (2010) 'Visual scenario analysis: understanding human factors of planning in rail engineering', Production 
Planning \& Control, Vol. 21, No. 4, pp.386-398.

Simola, A. (2005) Safety Leadership as a Line Supervisor's Task. A Case Study of the Implementation of a Long-Term Development Project at a Steel Works. University of Oulu.

Sinclair, M. (1991) 'Subjective assessment', in Wilson, J.R. and Corlett, E. (Eds.), Evaluation of Human Work: A Practical Ergonomics Methodology, Taylor \& Francis, London, pp.58-88.

Strauss, A.L. and Corbin, J.M. (1998) Basics of Qualitative Research: Techniques and Procedures for Developing Grounded Theory, SAGE Publications.

Van Aken, J. (2004) 'Management research based on the paradigm of the design sciences: the quest for field-tested and grounded technological rules', Journal of Management Studies, Vol. 41, No. 2, pp.219-246.VR Group (2015) Annual report 2014. http://2014.vrgroupraportti.fi/en/annual-report-2014/ (Accessed 4 May 2017).

VR Group (2015) Annual report 2014. http://2014.vrgroupraportti.fi/en/annual-report2014/ (Accessed 4 May 2017).

Väyrynen, S., Jounila, H. and Latva-Ranta, J. (Eds.) (2015) Asenteet Mallillaan AseMa: Tutkimuksen loppuraportti [AseMa Project's Final Report] (in Finnish), University of Oulu, Finland.

Wilson, J.R. (2013) 'Systems approaches in ergonomics/human factors applied within rail systems engineering', in Dadashi, N. et al. (Eds.), Rail Human Factors: Supporting Reliability, Safety and Cost Reduction, Taylor \& Francis, London, pp.463-472.

Wilson, J.R. (2014) 'Fundamentals of systems ergonomics/human factors', Applied Ergonomics, Vol. 45, No. 1, pp.5-13.Wilson, J.R., Ryan, B., Schock, A., Ferreira, P., Smith, S. and Pitsopoulos, J. (2008) 'Understanding safety and production risks in rail engineering planning and protection', Ergonomics, Vol. 52, No. 7, pp.774790.

Wilson, J.R., Ryan, B., Schock, A., Ferreira, P., Smith, S. and Pitsopoulos, J. (2008) 'Understanding safety and production risks in rail engineering planning and protection', Ergonomics, Vol. 52, No. 7, pp.774-790.

Zohar, D. (1980) 'Safety climate in the industrial organizations: theoretical and applied implications', Journal of Applied Psychology, Vol. 65, No. 1, pp.96-102. 
Table 1. Respondents' gender, age and work status distribution by business sector

\begin{tabular}{|c|c|c|c|c|c|}
\hline & $\begin{array}{c}\text { Passenger } \\
\text { services } \\
n(\%)\end{array}$ & $\begin{array}{c}\text { Logistics } \\
n(\%)\end{array}$ & $\begin{array}{c}\text { Infrastructure } \\
\text { engineering } \\
n(\%)\end{array}$ & $\begin{array}{c}\text { Maintenance } \\
n(\%)\end{array}$ & $\begin{array}{c}\text { Train } \\
\text { operations } \\
n(\%)\end{array}$ \\
\hline \multicolumn{6}{|c|}{ Gender distribution } \\
\hline Men & $165(60.0)$ & $123(89.8)$ & $186(84.5)$ & $137(92.6)$ & $233(94.3)$ \\
\hline Women & $97(35.3)$ & $4(2.9)$ & $31(14.1)$ & $7(4.7)$ & $9(3.6)$ \\
\hline No information & $13(4.7)$ & $10(7.3)$ & $3(1.4)$ & $4(1.4)$ & $5(2.0)$ \\
\hline \multicolumn{6}{|l|}{ Age distribution } \\
\hline $\begin{array}{l}\text { Young (Below } 34 \\
\text { years old) }\end{array}$ & $73(26.5)$ & $31(22.6)$ & $54(24.5)$ & $14(9.5)$ & $104(42.1)$ \\
\hline $\begin{array}{l}\text { Middle-aged } \\
\text { (from } 34 \text { to } 54 \\
\text { years old) }\end{array}$ & $133(48.4)$ & $60(43.8)$ & $85(38.6)$ & $67(45.3)$ & $122(49.4)$ \\
\hline Over 54 years old & $66(24.0)$ & $44(32.1)$ & 79 (35.9) & 65 (43.9) & $21(8.5)$ \\
\hline No information & $3(1.1)$ & $2(1.5)$ & $2(0.9)$ & $2(1.4)$ & $0(0.0)$ \\
\hline \multicolumn{6}{|l|}{ Work status } \\
\hline Employee & $216(78.5)$ & $82(59.9)$ & $73(33.2)$ & $69(46.6)$ & 195 (78.9) \\
\hline $\begin{array}{l}\text { Expert/ } \\
\text { management } \\
\text { level }\end{array}$ & $53(19.3)$ & $53(38.7)$ & $144(65.5)$ & $77(52.0)$ & $52(21.1)$ \\
\hline No information & $6(2.2)$ & $2(1.5)$ & $3(1.4)$ & $2(1.4)$ & $0(0.0)$ \\
\hline
\end{tabular}




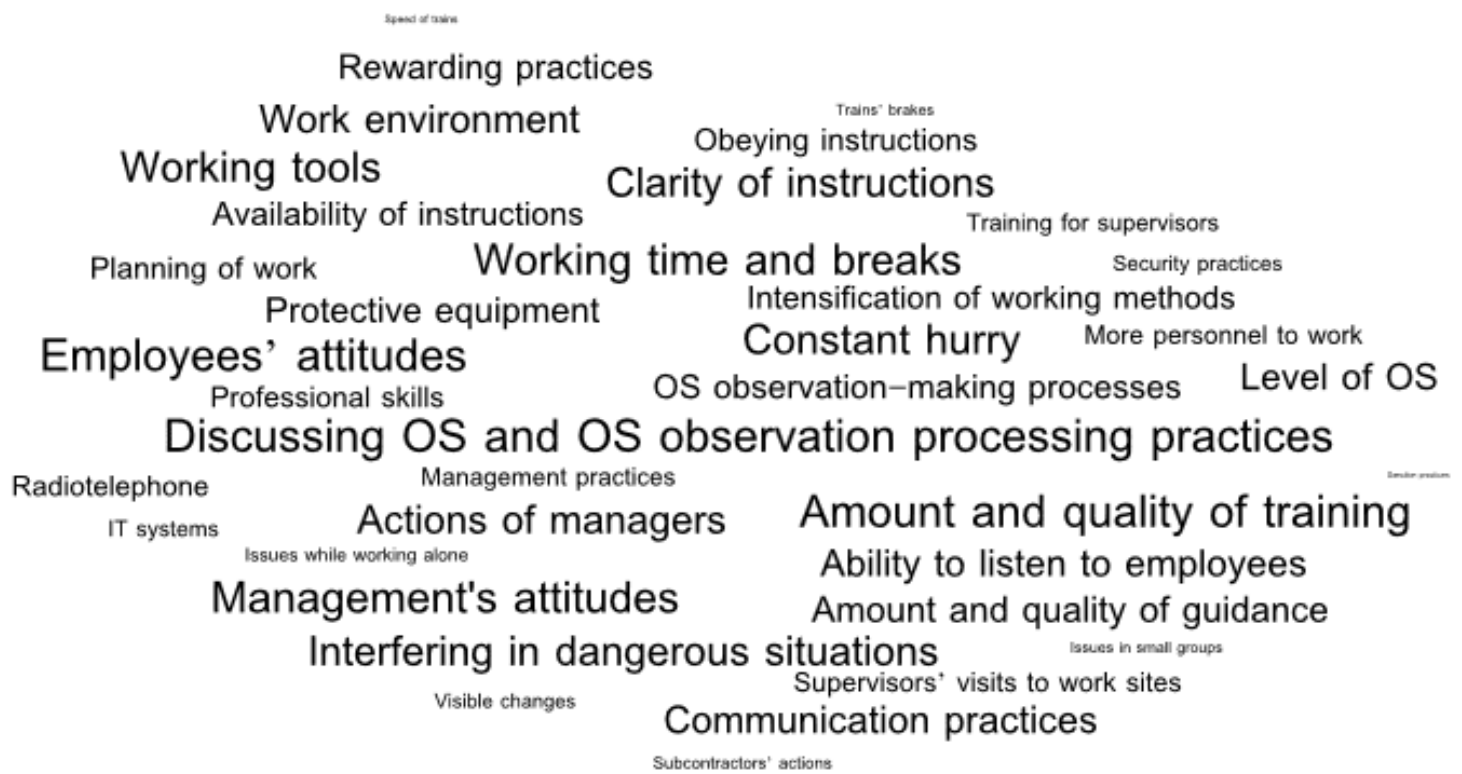

Figure 1. Identified themes. Font size reflects the frequency of the themes in the answers. 
Table 2. Distribution of themes between the employees' and others' (management and experts) groups (respondents with no background information $(N=13)$ were excluded). The first column shows the identified themes and their amounts in all answers and the other columns show how many times a particular theme appears in employees' and others' answers.

\begin{tabular}{|c|c|c|c|}
\hline Theme & $\begin{array}{l}\text { Employees } \\
n(\%)\end{array}$ & $\begin{array}{c}\text { Others } \\
n(\%)\end{array}$ & $\begin{array}{l}\text { Chi -square } \\
\text { (p-value) }\end{array}$ \\
\hline $\begin{array}{l}\text { 1. Discussing OS and OS observation- } \\
\text { processing practices }(N=152)\end{array}$ & $51(3.8)$ & $100(12.7)$ & .000 \\
\hline 2. Amount and quality of training $(N=147)$ & $90(6.7)$ & $55(7.0)$ & .850 \\
\hline 3. Employees' attitudes $(N=147)$ & $67(5.0)$ & $77(9.8)$ & .000 \\
\hline 4. Management's attitudes $(N=131)$ & $75(5.6)$ & $54(6.9)$ & .423 \\
\hline 5. Working time and breaks $(N=123)$ & $107(8.0)$ & $16(2.0)$ & .000 \\
\hline 6. Working tools $(N=121)$ & $91(6.8)$ & $28(3.6)$ & .000 \\
\hline 7. Constant hurry $(N=101)$ & $87(6.5)$ & $13(1.7)$ & .000 \\
\hline 8. Interfering in dangerous situations $(N=98)$ & $61(4.6)$ & $36(4.6)$ & .746 \\
\hline 9. Clarity of instructions $(N=98)$ & $58(4.3)$ & $40(5.1)$ & .643 \\
\hline 10. Actions of managers $(N=92)$ & $63(4.7)$ & $29(3.7)$ & .143 \\
\hline 11. Work environment $(N=87)$ & $71(5.3)$ & $16(2.0)$ & .000 \\
\hline 12. Communication practices $(N=83)$ & $47(3.5)$ & $36(4.6)$ & .357 \\
\hline 13. Ability to listen to employees $(N=72)$ & $50(3.7)$ & $22(2.8)$ & .145 \\
\hline 14. Level of OS $(N=61)$ & $40(3.0)$ & $21(2.7)$ & .486 \\
\hline 15. Amount and quality of guidance $(N=58)$ & $36(2.7)$ & $22(2.8)$ & .909 \\
\hline 16. Protective equipment $(N=56)$ & $33(2.5)$ & $23(2.9)$ & .701 \\
\hline 17. Rewarding practices $(N=54)$ & $15(1.1)$ & $39(5.0)$ & .000 \\
\hline 18. OS observation-making processes $(N=49)$ & $27(2.0)$ & $20(2.5)$ & .573 \\
\hline 19. Availability of instructions $(N=42)$ & $26(1.9)$ & $16(2.0)$ & .941 \\
\hline $\begin{array}{l}\text { 20. Intensification of working methods }(N= \\
\text { 41) }\end{array}$ & $25(1.9)$ & $16(2.0)$ & .959 \\
\hline 21. Obeying instructions $(N=39)$ & $27(2.0)$ & $12(1.5)$ & .304 \\
\hline 22. Planning of work $(N=38)$ & $29(2.2)$ & $9(1.1)$ & .054 \\
\hline 23. Professional skills $(N=36)$ & $26(1.9)$ & $9(1.1)$ & .110 \\
\hline 24. Radiotelephone $(N=35)$ & $26(1.9)$ & $8(1.0)$ & .066 \\
\hline 25. Supervisors' visits to work sites $(N=30)$ & $20(1.5)$ & $10(1.3)$ & .545 \\
\hline 26. More personnel to work $(N=25)$ & $21(1.6)$ & $3(0.4)$ & .008 \\
\hline 27. Management practices $(N=20)$ & $10(0.7)$ & $10(1.3)$ & .292 \\
\hline 28. Training for supervisors $(N=18)$ & $6(0.4)$ & $12(1.5)$ & .014 \\
\hline 29. IT systems $(N=16)$ & $5(0.4)$ & $11(1.4)$ & .013 \\
\hline 30. Security practices $(N=15)$ & $12(0.9)$ & $3(0.4)$ & .135 \\
\hline 31. Visible changes $(N=13)$ & $7(0.5)$ & $6(0.8)$ & .576 \\
\hline 32. Issues while working alone $(N=11)$ & $8(0.6)$ & $3(0.4)$ & * \\
\hline 33. Subcontractors' actions $(N=10)$ & $5(0.4)$ & $5(0.6)$ & $*$ \\
\hline 34. Trains' brakes $(N=7)$ & $4(0.3)$ & $1(0.1)$ & ** \\
\hline
\end{tabular}




\begin{tabular}{|c|c|c|c|}
\hline Theme & $\begin{array}{c}\text { Employees } \\
n(\%)\end{array}$ & $\begin{array}{c}\text { Others } \\
n(\%)\end{array}$ & $\begin{array}{c}\text { Chi -square } \\
\text { (p-value) }\end{array}$ \\
\hline 35. Issues in small groups $(N=7)$ & $6(0.4)$ & $1(0.1)$ & ${ }^{* *}$ \\
\hline 36. Speed of trains $(N=5)$ & $4(0.3)$ & $1(0.1)$ & $* *$ \\
\hline 37. Sanction practices $(N=3)$ & 0 & $3(0.4)$ & ** \\
\hline
\end{tabular}

Significance at the .05 level.

* One cell $(25.0 \%)$ has an expected count less than 5.

** Two cells $(50.0 \%)$ have an expected count less than 5 
Table 3. Distribution of themes by business sector (respondents with no background information $(N=68)$ were excluded). The first column shows the identified themes and their amounts in all answers and the other columns show how many times a particular theme appears in each business sector's answers.

\begin{tabular}{|c|c|c|c|c|c|c|}
\hline Theme & $\begin{array}{c}\text { Passenger } \\
\text { services } \\
n(\%) \\
\end{array}$ & $\begin{array}{l}\text { Logistics } \\
n(\%)\end{array}$ & $\begin{array}{c}\text { Infrastructure } \\
\text { engineering } \\
n(\%)\end{array}$ & $\begin{array}{c}\text { Maintenance } \\
n(\%)\end{array}$ & $\begin{array}{c}\text { Train } \\
\text { operations } \\
n(\%) \\
\end{array}$ & $\begin{array}{c}\text { Chi -square } \\
(p \text {-value })\end{array}$ \\
\hline $\begin{array}{l}\text { 1. Discussing OS and OS } \\
\text { observation-processing } \\
\text { practices }(N=152)\end{array}$ & $38(7.2)$ & $11(4.0)$ & $32(8.4)$ & $23(8.2)$ & $29(5.1)$ & .306 \\
\hline $\begin{array}{l}\text { 2. Amount and quality of } \\
\text { training }(N=147)\end{array}$ & $44(8.3)$ & $16(5.8)$ & $26(6.8)$ & $29(10.3)$ & $25(4.4)$ & .051 \\
\hline $\begin{array}{l}\text { 3. Employees' attitudes } \\
(N=147)\end{array}$ & $32(6.0)$ & $18(6.6)$ & $38(9.9)$ & $26(9.2)$ & $27(4.7)$ & .143 \\
\hline $\begin{array}{l}\text { 4. Management's attitudes } \\
(N=131)\end{array}$ & $23(4.3)$ & $6(2.2)$ & $36(9.4)$ & $21(7.4)$ & $41(7.2)$ & .001 \\
\hline $\begin{array}{l}\text { 5. Working time and } \\
\text { breaks }(N=123)\end{array}$ & $22(4.2)$ & $12(4.4)$ & $6(1.6)$ & $4(1.4)$ & $76(13.3)$ & .000 \\
\hline 6 . Working tools $(N=121)$ & $36(6.8)$ & $22(8.0)$ & $17(4.4)$ & $15(5.3)$ & $24(4.2)$ & .104 \\
\hline $\begin{array}{l}\text { 7. Constant hurry }(N= \\
101)\end{array}$ & $19(3.6)$ & $6(2.2)$ & $15(3.9)$ & $8(2.8)$ & $51(8.9)$ & .000 \\
\hline $\begin{array}{l}\text { 8. Interfering in dangerous } \\
\text { situations }(N=98)\end{array}$ & $31(5.8)$ & $12(4.4)$ & $15(3.9)$ & $14(5.0)$ & $22(3.8)$ & .560 \\
\hline $\begin{array}{l}\text { 9. Clarity of instructions } \\
(N=98)\end{array}$ & $22(4.2)$ & $12(4.4)$ & $19(5.0)$ & $11(3.9)$ & $33(5.8)$ & .196 \\
\hline $\begin{array}{l}\text { 10. Actions of managers } \\
(N=92)\end{array}$ & $14(2.6)$ & $5(1.8)$ & $22(5.7)$ & $10(3.5)$ & $40(7.0)$ & .000 \\
\hline $\begin{array}{l}\text { 11. Work environment } \\
(N=87)\end{array}$ & $27(5.1)$ & $23(8.4)$ & $12(3.1)$ & $11(3.9)$ & $7(1.2)$ & .000 \\
\hline $\begin{array}{l}\text { 12. Communication } \\
\text { practices }(N=83)\end{array}$ & $20(3.8)$ & $13(4.7)$ & $12(3.1)$ & $8(2.8)$ & $23(4.0)$ & .371 \\
\hline $\begin{array}{l}\text { 13. Ability to listen to } \\
\text { employees }(N=72)\end{array}$ & $20(3.8)$ & $15(5.5)$ & $12(3.1)$ & $10(3.5)$ & $15(2.6)$ & .348 \\
\hline $\begin{array}{l}\text { 14. Level of OS } \\
(N=61)\end{array}$ & $15(2.8)$ & $7(2.6)$ & $9(2.3)$ & $10(3.5)$ & $19(3.3)$ & .525 \\
\hline $\begin{array}{l}\text { 15. Amount and quality of } \\
\text { guidance }(N=58)\end{array}$ & $13(2.5)$ & $6(2.2)$ & $14(3.7)$ & $12(4.3)$ & $8(1.4)$ & .247 \\
\hline $\begin{array}{l}\text { 16. Protective equipment } \\
(N=56)\end{array}$ & $8(1.5)$ & $11(4.0)$ & $11(2.9)$ & $7(2.5)$ & $17(3.0)$ & .160 \\
\hline $\begin{array}{l}\text { 17. Rewarding practices } \\
(N=54)\end{array}$ & $12(2.3)$ & $2(0.7)$ & $14(3.7)$ & $11(3.9)$ & $10(1.7)$ & .124 \\
\hline $\begin{array}{l}\text { 18. OS observation- } \\
\text { making processes }(N=49)\end{array}$ & $24(4.5)$ & $3(1.1)$ & $6(1.6)$ & $7(2.5)$ & $9(1.6)$ & .007 \\
\hline $\begin{array}{l}\text { 19. Availability of } \\
\text { instructions }(N=42)\end{array}$ & $10(1.9)$ & $3(1.1)$ & $5(1.3)$ & $6(2.1)$ & $14(2.4)$ & .300 \\
\hline $\begin{array}{l}\text { 20. Intensification of } \\
\text { working methods }(N=41)\end{array}$ & $9(1.7)$ & $6(2.2)$ & $12(3.1)$ & $6(2.1)$ & $5(0.9)$ & .377 \\
\hline $\begin{array}{l}\text { 21. Obeying instructions } \\
(N=39)\end{array}$ & $6(1.1)$ & $6(2.2)$ & $7(1.8)$ & $6(2.1)$ & $13(2.3)$ & .424 \\
\hline $\begin{array}{l}\text { 22. Planning of work } \\
(N=38)\end{array}$ & $9(1.7)$ & $5(1.8)$ & $7(1.8)$ & $2(0.7)$ & $15(2.6)$ & .165 \\
\hline $\begin{array}{l}\text { 23. Professional skills } \\
(N=36)\end{array}$ & $10(1.9)$ & $8(2.9)$ & $1(0.3)$ & $4(1.4)$ & $12(2.1)$ & $*$ \\
\hline $\begin{array}{l}\text { 24. Radiotelephone } \\
(N=35)\end{array}$ & $0(0.0)$ & $30(10.9)$ & $0(0.0)$ & $1(0.4)$ & $2(0.3)$ & $* *$ \\
\hline $\begin{array}{l}\text { 25. Supervisors' visits to } \\
\text { work sites }(N=30)\end{array}$ & $8(1.5)$ & $3(1.1)$ & $9(2.3)$ & $4(1.4)$ & $5(0.9)$ & $* *$ \\
\hline $\begin{array}{l}\text { 26. More personnel to } \\
\text { work }(N=25)\end{array}$ & $16(3.0)$ & $0(0.0)$ & $4(1.0)$ & $1(0.4)$ & $4(0.7)$ & $* *$ \\
\hline $\begin{array}{l}\text { 27. Management practices } \\
(N=20)\end{array}$ & $6(1.1)$ & $0(0.0)$ & $3(0.8)$ & $2(0.7)$ & $8(1.4)$ & $* * *$ \\
\hline
\end{tabular}




\begin{tabular}{|l|c|c|c|c|c|c|}
\hline Theme & $\begin{array}{c}\text { Passenger } \\
\text { services } \\
\boldsymbol{n}(\boldsymbol{\%})\end{array}$ & $\begin{array}{c}\text { Logistics } \\
\boldsymbol{n}(\boldsymbol{\%})\end{array}$ & $\begin{array}{c}\text { Infrastructure } \\
\text { engineering } \\
\boldsymbol{n}(\boldsymbol{\%})\end{array}$ & $\begin{array}{c}\text { Maintenance } \\
\boldsymbol{n}(\boldsymbol{\%})\end{array}$ & $\begin{array}{c}\text { Train } \\
\text { operations } \\
\boldsymbol{n}(\boldsymbol{\%})\end{array}$ & $\begin{array}{c}\text { Chi -square } \\
(\boldsymbol{p} \text {-value) }\end{array}$ \\
\hline $\begin{array}{l}\text { 28. Training for } \\
\text { supervisors }(N=18)\end{array}$ & $4(0.8)$ & $1(0.4)$ & $2(0.5)$ & $4(1.4)$ & $5(0.9)$ & $* * * *$ \\
\hline $\begin{array}{l}29 . \text { IT systems }(N=16) \\
2(0.4)\end{array}$ & $2(0.7)$ & $1(0.3)$ & $7(2.5)$ & $2(0.3)$ & $* * * *$ \\
\hline $\begin{array}{l}30 . \text { Security practices } \\
(N=15)\end{array}$ & $11(2.1)$ & $0(0.0)$ & $2(0.5)$ & $1(0.4)$ & $1(0.2)$ & $* * * *$ \\
\hline $\begin{array}{l}31 . \text { Visible changes } \\
(N=13)\end{array}$ & $3(0.6)$ & $4(1.5)$ & $2(0.5)$ & $0(0.0)$ & $4(0.7)$ & $* * * *$ \\
\hline $\begin{array}{l}32 . \text { Issues while working } \\
\text { alone }(N=11)\end{array}$ & $6(1.1)$ & $3(1.1)$ & $2(0.5)$ & $0(0.0)$ & $0(0.0)$ & $* * * *$ \\
\hline $\begin{array}{l}33 . \text { Subcontractors' actions } \\
(N=10)\end{array}$ & $3(0.6)$ & $0(0.0)$ & $4(1.0)$ & $1(0.4)$ & $1(0.2)$ & $* * * *$ \\
\hline $\begin{array}{l}34 . \text { Trains' brakes }(N=7) \\
1(0.2)\end{array}$ & $2(0.7)$ & $0(0.0)$ & $0(0.0)$ & $4(0.7)$ & $* * * *$ \\
\hline $\begin{array}{l}35 . \text { Issues in small groups } \\
(N=7)\end{array}$ & $2(0.4)$ & $1(0.4)$ & $4(1.0)$ & $0(0.0)$ & $0(0.0)$ & $* * * *$ \\
\hline 36. Speed of trains $(N=5)$ & $3(0.6)$ & $0(0.0)$ & $0(0.0)$ & $0(0.0)$ & $2(0.3)$ & $* * * *$ \\
\hline $\begin{array}{l}37 . \text { Sanction practices } \\
(N=3)\end{array}$ & $1(0.2)$ & $0(0.0)$ & $2(0.5)$ & $0(0.0)$ & $0(0.0)$ & $* * * *$ \\
\hline
\end{tabular}

Significant at .05 level

* One cell $(25.0 \%)$ has an expected count less than 5.

** Two cells $(50.0 \%)$ have an expected count less than 5 .

*** Four cells (40.0\%) have an expected count less than 5.

**** Five cells $(50.0 \%)$ have an expected count less than 5. 
Table 4. The 26 proposed safety meeting themes (Phase 1) and the 20 final safety meeting themes (Phase 2) (in alphabetical order)

\begin{tabular}{|c|c|}
\hline Initial 26 proposed safety meeting themes & Final 20 safety meeting themes decided in Focus Group I \\
\hline Actions when a co-worker has a seizure & 1. Actions when a co-worker has a seizure \\
\hline Customer service and dealing with difficult customers & 2. Customer service and dealing with difficult customers \\
\hline Discussing accidents at the accident location & 3. Discussing accidents at the accident location \\
\hline Discussing problems noticed by personnel & 4. $\quad$ Discussing problems noticed by personnel \\
\hline Exercising during breaks & 5. $\quad$ Exercising during breaks \\
\hline Effective internal communication & 6. Effective internal communication \\
\hline Risks in new or rarely performed tasks & \multirow{2}{*}{ 7. Holistic risk management } \\
\hline Personnel risk management and safety observations & \\
\hline \multirow{2}{*}{ Mental well-being } & 8. Mental well-being \\
\hline & 9. The impact of stress on OS \\
\hline New instructions and changes & 10. New instructions and changes \\
\hline \multirow{2}{*}{ OS in different seasons } & 11. OS in summer conditions \\
\hline & 12. OS in winter conditions \\
\hline Participation and idea collection & 13. Participation and idea collection \\
\hline Physical ergonomics & 14. Physical ergonomics \\
\hline Safety during home and leisure time & \multirow{2}{*}{ 15. Safety during commute and during home and leisure time } \\
\hline Safety during commute & \\
\hline Cleanliness and order in the working environment & \multirow{3}{*}{ 16. Safety in the working environment } \\
\hline $\begin{array}{l}\text { The right protective equipment and working tools for different } \\
\text { tasks }\end{array}$ & \\
\hline How to make your own working environment safe & \\
\hline Safety-oriented attitude & 17. Safety-oriented attitude \\
\hline Taking care of others at work & 18. Taking care of others at work \\
\hline Topical issues (e.g. changes in work) & 19. Topical issues (e.g. changes in work) \\
\hline Zero-accident philosophy & 20. Zero-accident philosophy \\
\hline $\begin{array}{l}\text { How to act in different disaster situations (e.g. fire, poisonous } \\
\text { leak) }\end{array}$ & $\begin{array}{l}\text { Not included in the final safety meeting themes because the } \\
\text { case company already has guidelines for disaster situations }\end{array}$ \\
\hline Taking risks, obeying instructions & $\begin{array}{l}\text { Not included in the final safety meeting themes because the } \\
\text { case company did not currently consider this as relevant as the } \\
\text { other themes }\end{array}$ \\
\hline $\begin{array}{l}\text { Showing employees how to utilise the case company's safety } \\
\text { observation systems and orientation material }\end{array}$ & $\begin{array}{l}\text { Not included in the final safety meeting themes because the } \\
\text { case company did not currently consider this as relevant as the } \\
\text { other themes }\end{array}$ \\
\hline Showing employees how to utilise the case company's videos & $\begin{array}{l}\text { Not included in the final safety meeting themes because the } \\
\text { case company did not currently consider this as relevant as the } \\
\text { other themes }\end{array}$ \\
\hline
\end{tabular}

